\title{
1 Signalling by tips
}

2 José A Feijó ${ }^{1,2}$, Sílvia S Costa ${ }^{1,2}$, Ana Margarida Prado ${ }^{1,2}$, Jörg D Becker ${ }^{1}$

\section{3 and Ana Catarina Certal ${ }^{1}$}

4 New molecules, including protein kinases, lipids and

5 molecules that have neurotransmitter activities in animals,

6 continue to be described as important players in tip-

7 growing cells. Transcriptomics is beginning to show that

8 the largest single class of genes expressed in pollen tubes

9 encode signal transducers, reflecting the necessity to

10 decode all of the different pathways that are associated

11 with tip growth. Many of these pathways may use common

12 intracellular second messengers, with ions and reactive

13 oxygen species emerging as two major common

14 denominators in many of the processes involved in tip

15 growth. These second messengers might influence the

16 actin cytoskeleton through known interactions with actin-

17 binding proteins. In turn, changes in the dynamic

18 properties of the cytoskeleton would define the basic

19 polarity events needed to shape and modify tip-growing

20 cells.

\section{Addresses}

22 'Centro de Biologia do Desenvolvimento, Instituto Gulbenkian de

23 Ciência, P-2780-156 Oeiras, Portugal; e-mail: jfeijo@fc.ul.pt

$24{ }^{2}$ Universidade de Lisboa, Faculdade de Ciências, Departamento

25 de Biologia Vegetal, Campo Grande, P-1749-016 Lisboa,

26 Portugal

Current Opinion in Plant Biology 2004, 7:

This review comes from a themed issue on

Cell signalling and gene regulation

Edited by Jennifer Sheen and Steven Kay

1369-5266/\$ - see front matter

(c) 2004 Elsevier Ltd. All rights reserved.

\section{Abbreviations}

ABA abscisic acid

ADF actin-depolymerising factor

AIP1 ACTIN-INTERACTING PROTEIN1

GABA $\gamma$-amino butyric acid

Lat52 [Please define.]

LePRK Lycopersicon esculentum POLLEN RECEPTOR

KINASE

MAPK mitogen-activated protein kinase

NO nitric oxide

pop2 [Please define.]

rhd2 root-hair defective2

ROS reactive oxygen species

SAGE serial analysis of gene expression

WASP Wiskott-Aldrich syndrome protein

\section{Introduction}

Tip-growing cells undergo an extreme type of polarised growth. Their growth is based on the occurrence of elongation exclusively at the apex, which is fuelled by newly synthesised membrane delivered by vectorial
49 exocytosis. Tip-growing cells are probably the fastest 50 linearly growing cells in nature. Furthermore, they have 51 been perfected by evolution as machines that sense

52 subtle extracellular signals and environmental changes,

53 and that develop by changing their growth axis 54 accordingly. In plants, there are two highly 55 differentiated types of tip-growing cells: root hairs and 56 pollen tubes. Root hairs have to sense the soil 57 environment and grow so as to maximise water and ion 58 uptake; they also respond to biotic stimuli, which may 59 result in the establishment of sophisticated symbioses. 60 Pollen tubes, on the other hand, have to communicate 61 their 'self' properties (i.e. information about species and 62 individuality) to the external stigma cells. These cells 63 continuously interact with the female tissues to scout 64 and find the right path into the open ovary cavity, until 65 they reach the micropyle's tiny opening and deliver 66 sperm.

67 The biological functions of both of these cell types 68 imply an innate capacity to communicate with and to 69 decode signals from their environment. It no surprise 70 that signalling is likely to play a central role in defining 71 these cell types. Many groups have focussed on 72 signalling within tip-growing cells and have produced a 73 significant body of information [1-5]. In this review, we 74 highlight some recent developments in our 75 understanding of signalling in apically growing plant 76 cells.

\section{Re-staging a classic with new actors}

78 Tip-growing cells were identified some time ago as a good system in which to investigate known signalling molecules and mechanisms, and in which to discover new ones [5]. Besides the huge amount of information compiled on the self-incompatibility system, which is beyond the scope of this review, a paradigmatic view of the sophisticated signalling system within the pollentube has been uncovered through the description of the LePRK pollen receptor kinase signalling complex. In mature pollen, LePRK2 and LePRK1 are bound to each other in a complex, and the secreted protein Lat52 is associated with the LePRK2 [6]. In the presence of style extract, however, LePRK2 is de-phosphorylated and both LePRK1 and Lat52 are released. These observations suggest a model in which pistil ligands induce the dissociation of the complex and the release of the partners, including cytoplasmic partners that transduce the signal to the pollen tube $\left[7^{\circ}\right]$. Recently, new interactors of LePRK1 and LePRK2 have been described, namely LeSHY and LeSTIG [Please define the abbreviations LeSHY and LeSTIG.] [8]. Exogenous LeSTIG abolished the interaction between Lat52 and LePRK2, and promoted pollen-tube growth in vitro. These findings are consistent with model that LePRK1 and LePRK2 might interact with different 

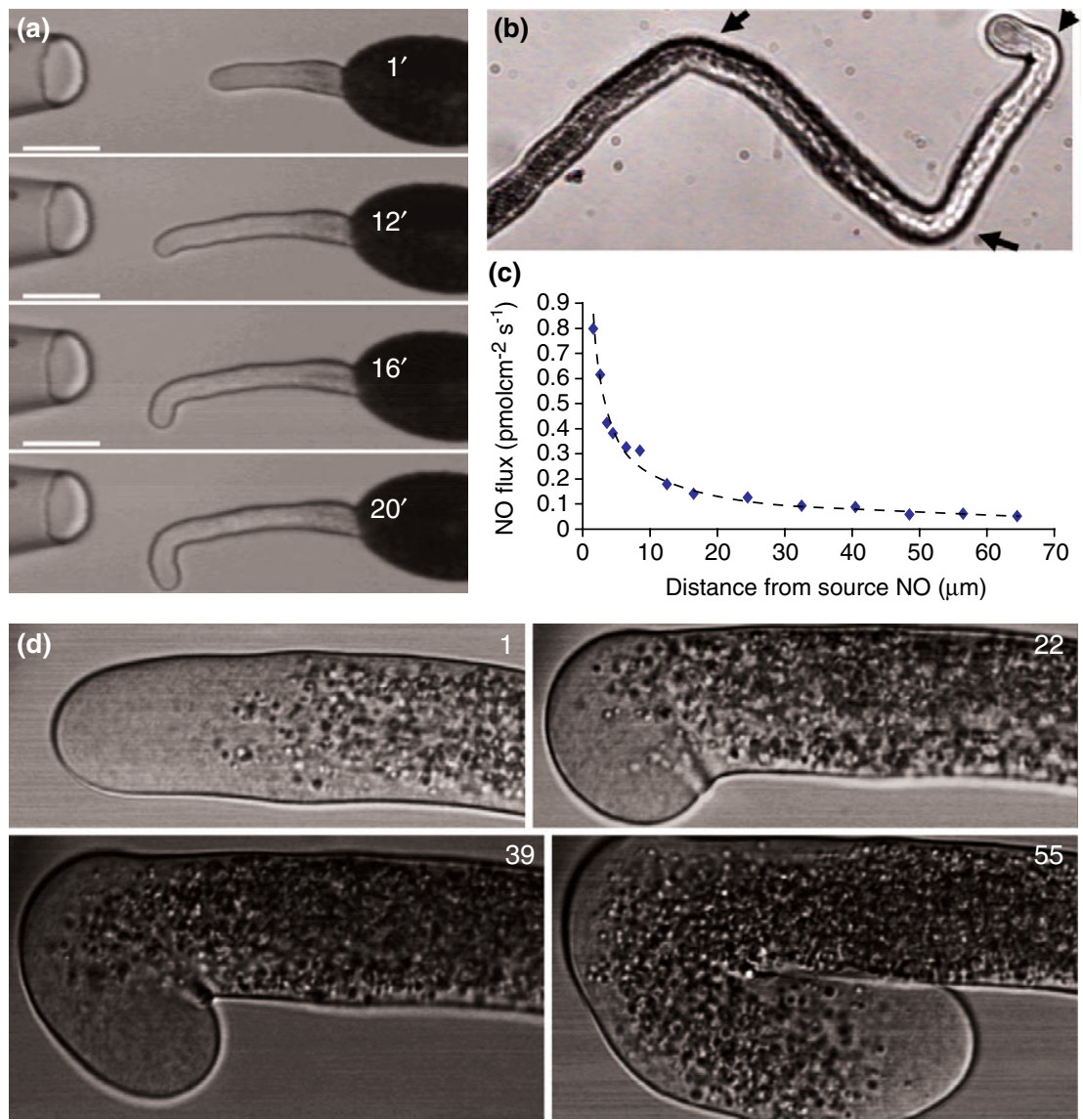

103

\section{Figure 1}

Current Opinion in Plant Biology

(a) Time-lapse sequence of a Lilium longiflorum (lily) pollen-tube growing facing an extra-cellular NO point-source (SNAP [Please define SNAP.] on agarose [shown on the left of the image]). The growth of the pollen tube slows as it moves into the NO gradient, but the direction of growth was unchanged for about $12 \mathrm{~min}$. A new growth axis then starts to be defined, forming a sharp right-angle from the original axis $\left(97.7^{\circ} \pm 3.6\right.$, $n=28$ ). The pollen tube then regains its normal growth rate (after 16-20 $\mathrm{min})(B a r=30 \mu \mathrm{m})$. (b) Lily pollen tube showing three consecutive re-orientation responses, which were induced by moving the same source to the locations marked with arrows. The growth axis moved reproducibly by right angles after each challenge by the NO source facing the pollen-tube tip. (c) Artificial NO-source measurements obtained by using a vibrating self-referenced polarographic probe to NO. The graph shows a typical exponential NO-gradient decay from the point source at different step distances. (d) Time-lapse sequence of a pollen tube being challenged with a diluted NO artificial source in the presence of sildenafil citrate $\left(V_{i a g r a}{ }^{T M}\right)$ (numbers at the right-hand upper corner represent minutes after detection of the response). When these diluted sources are used, most pollen tubes do not show any response, often running into the pipette. For this experiment, pollen tubes were first incubated on standard medium and challenged with the diluted NO source. Despite the lower amount of NO used, reverse re-orientation angles were observed in the presence of sildenafil citrate $\left(109.8^{\circ} \pm 9.8, n=9\right)$ showing a sensitisation effect, from unresponsive to peak response (adapted from $\left.\left[10^{\bullet \bullet}\right]\right)$.

ligands at different stages of the growth of the pollen tube through the style, but unexpected molecules have also entered the scene.

Two molecules that have neurotransmitter properties in animals were recently found to be involved in pollentube growth. $\gamma$-amino butyric acid (GABA) was shown genetically to be involved in the growth and guidance mechanisms of Arabidopsis pollen tubes [9*]; the pollen tubes of $p \circ p 2$ mutants are strongly impaired in their capacity to grow both in vivo and in vitro in the presence of GABA. POP2 was convincingly demonstrated to encode a transaminase that is involved in the degradation of GABA. We have recently demonstrated a new role for nitric oxide $(\mathrm{NO})$ in the regulation of pollen-tube growth in Lilium longiflorum, especially in the re-orientation response (Figure 1). NO may be involved in finding a suitable path for the pollen tube,

\section{6}

137 possibly through a cGMP transduction pathway [10*0]. $138 \mathrm{NO}$ is a ubiquitous signalling molecule in animals [11], 139 and growing evidence points to its widespread 140 production and effects in plants [12,13]. Evidence has 141 been found recently for enzymatic synthesis of NO in 142 plants, involving both the constitutive enzyme 143 Arabidopsis thaliana NO SYNTHASE1 (AtNOS1) [14] 144 and/or inducible NO-synthase enzymes [15]. Nitrate 145 reductase and xanthine oxireductase are also generally 146 accepted to produce NO in plants [16]. Because of the 147 largely diffusible and reactive properties of NO, its 148 seems that the first reported role for NO in a tip149 growing cell $\left[10^{\circ}\right]$ is likely to be just one of several 150 significant roles for NO in these cells.

151 Lipid signalling also stages a major entrance in tip152 growing cells [17]. Of special notice, phosphatidic acid 153 and phospholipases (e.g. phospholipase D [PLD]) have 
Figure 2

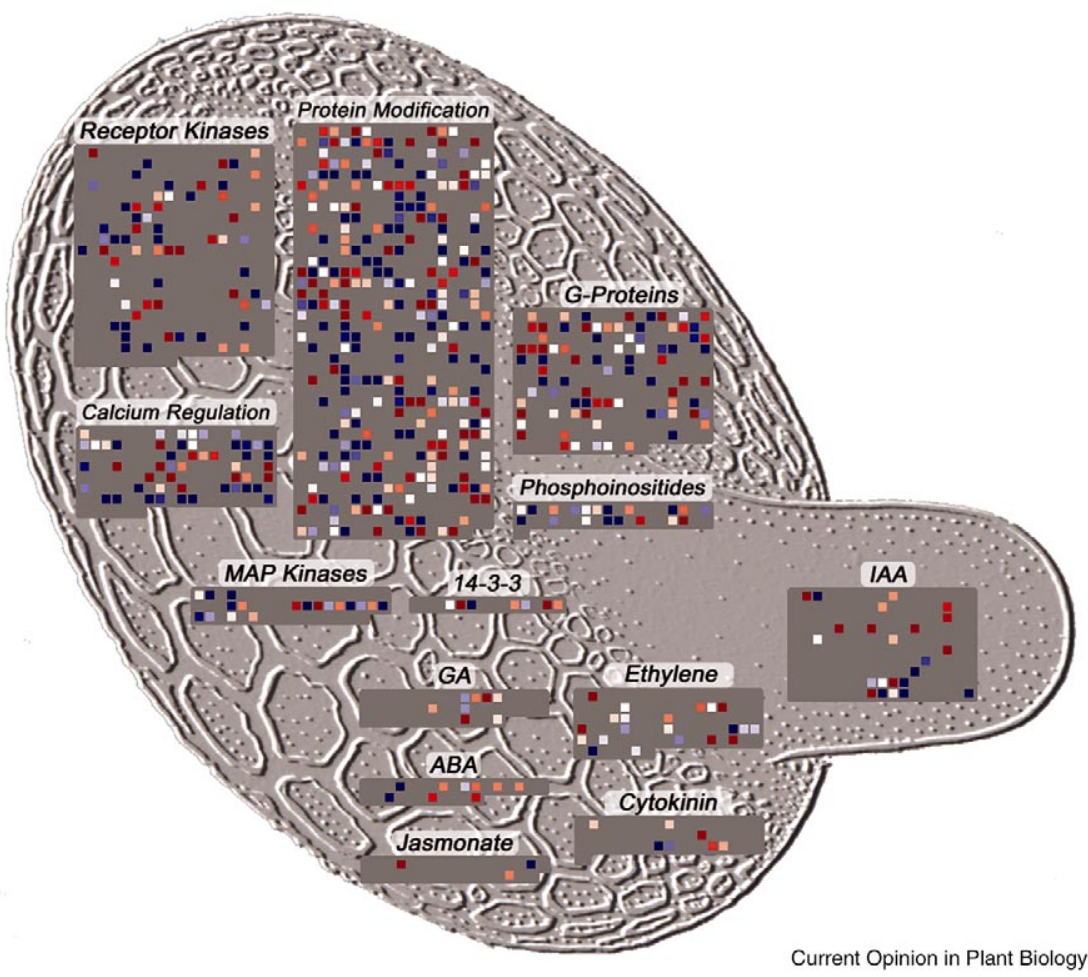

Gene expression data in pollen relative to vegetative tissues (i.e. leaves, seedlings and siliques) are depicted using the MAPMAN tool [24] to display the genomic dataset derived from work by JD Becker (unpublished). Genes are symbolised by colour-encoded boxes (red, downregulation; blue, upregulation; grey, absent call in pollen). Many genes in the classes 'protein modification' (protein kinases), 'receptor kinases', 'Gproteins' (GTPases and GTP-binding proteins) and 'calcium regulation' (calmodulins and calcium-dependent protein kinases) are enriched in pollen or even selectively expressed (see Table 1). These genes are probably involved in integrating signals from the female tissue with pollen-tube germination and growth processes, thus leading to a successful fertilisation. By contrast, genes that are involved in 'hormone metabolism' are in general downregulated in pollen, with a few exceptions mainly in auxin-induced proteins. Thus, the responses of pollen tubes to hormones might be either negligible or restricted to very specific responses.

been shown to play fundamental roles in root-hair $\left[18^{\circ}\right]$ and pollen-tube development $\left[19^{\circ}, 20^{\circ}\right]$. An elegant set of experiments that involved osmotic manipulations of tobacco pollen signals established several phosphotadylinositols as downstream effectors of the phosphatidic acid signal. This link builds up a scenario in which phospholipid signalling is likely to play a central role in many of the transduction pathways within tip-growing cells $\left[20^{\circ}\right]$.

The involvement of such a diversity of molecules in signalling in tip-growing cells is not surprising, and may well be necessary to provide specificity in many of the responses that these cells have to perform. The use of common fundamental molecules, although evolutionarily sensible, make sit less probable that a single molecule could convey all the information necessary for any given response. The diversity of signalling molecules within tip-growing cells also implies, however, that these cells employ sophisticated signalling mechanisms.

\section{What the genes have to say}

It is generally accepted that microsporogenesis involves the accumulation of significant levels of long-lived mRNA molecules within mature pollen; these mRNAs drive germination and early tube growth [5]. Thus, studies of the pollen transcriptome could presumably

\section{1}

192 be used to define the genetic fingerprint needed for tip 193 growth.

194 The importance of signalling processes in pollen 195 relative to that in other tissues can be inferred from 196 three recent studies of the pollen transcriptome of 197 Arabidopsis. Two groups used Affymetrix 8K Arabidopsis 198 GeneChips (covering about 8000 genes) to compare the 199 transcriptome of highly purified, cell-sorted pollen 200 grains with those of four vegetative tissues [21 ${ }^{\circ}$ ] or of 201 non-sorted pollen grains with those of four 202 developmental stages of the sporophyte [22 $]$. In 203 another approach, serial analysis of gene expression 204 (SAGE) was used to profile the transcriptome of pollen 205 under normal and chilling conditions [23. 206 normalisation protocols were used to correct for the 207 much lower number of genes called present in pollen 208 (less than half than that in vegetative tissues). The 209 GeneChip analysis revealed that as many as $25 \%$ of the 210 genes that were identified as selectively expressed in 211 pollen could be classified as being involved in signalling $212\left[21^{\circ}\right]$, whereas the SAGE analysis attributed $23 \%$ as 213 members of this class [23 ${ }^{\circ}$ ]. A more recent analysis using 214 the Affymetrix 24K Arabidopsis GeneChip revealed that $21516 \%$ of the 6587 genes that were expressed in pollen 216 were involved in signalling (as compared with $12 \%$ in 
Table 1.

\begin{tabular}{|c|c|c|c|c|c|c|c|c|c|c|c|c|c|}
\hline \multicolumn{14}{|c|}{ [Please provide a title for this table.] } \\
\hline \multirow[b]{2}{*}{$\begin{array}{l}\text { Functional } \\
\text { class }\end{array}$} & \multirow[b]{2}{*}{$\begin{array}{l}\text { Fold } \\
\text { change }\end{array}$} & \multirow{2}{*}{$\begin{array}{l}\text { Selectively } \\
\text { expressed } \\
\text { in pollen? }\end{array}$} & \multirow[b]{2}{*}{ Probe set } & \multirow[b]{2}{*}{ AGI ID } & \multirow[b]{2}{*}{ Gene annotation } & \multicolumn{2}{|l|}{$\begin{array}{r}\text { Pollen } \\
\text { Expression }\end{array}$} & \multirow{2}{*}{\multicolumn{2}{|c|}{$\begin{array}{r}\text { Leaf } \\
\text { Expression }\end{array}$}} & \multirow{2}{*}{\multicolumn{2}{|c|}{$\begin{array}{l}\text { Seedling } \\
\text { Expression }\end{array}$}} & \multirow{2}{*}{\multicolumn{2}{|c|}{$\begin{array}{l}\text { Silique } \\
\text { Expression }\end{array}$}} \\
\hline & & & & & & $\begin{array}{l}\text { Expression } \\
\text { value }\end{array}$ & Call & & & & & & \\
\hline $\begin{array}{l}\text { Receptor } \\
\text { kinase } \\
\text { Receptor }\end{array}$ & 249 & Yes & 246106_at & $\underline{\text { AT5G28680 }}$ & $\underline{0}$ CRPK1L & 9135 & $\mathrm{P}$ & 22 & A & 27 & A & 30 & A \\
\hline kinase & 143 & Yes & 257119_at & AT3G20190 & $\underline{0}$ LRR III & 11290 & $\mathrm{P}$ & 42 & A & 43 & A & 62 & A \\
\hline $\begin{array}{l}\text { Calcium } \\
\text { regulation } \\
\text { Calcium }\end{array}$ & 195 & Yes & 263450_at & AT2G31500 & o CPK24 & 11605 & $\mathrm{P}$ & 37 & A & 34 & A & 59 & A \\
\hline $\begin{array}{l}\text { regulation } \\
\text { Protein }\end{array}$ & 126 & Yes & 250308_at & AT5G12180 & $\underline{0}$ CPK17 & 7078 & $P$ & 31 & A & 33 & A & 40 & A \\
\hline $\begin{array}{l}\text { modification } \\
\text { Protein }\end{array}$ & 176 & Yes & 264284_at & AT1G61860 & RLCKVII & 12224 & $P$ & 43 & A & 40 & $A$ & 61 & A \\
\hline modification & 175 & Yes & 258600_at & AT3G02810 & RLCKVII & 7676 & $\mathrm{P}$ & 28 & A & 27 & A & 28 & A \\
\hline G-protein & 79 & Yes & 262742_at & AT1G28550 & $\begin{array}{l}\text { AtRABA1i } \\
\text { SGP1 monomeric }\end{array}$ & 3154 & $P$ & 33 & A & 33 & $A$ & 30 & A \\
\hline G-protein & 60 & $\underline{\text { No }}$ & 257951_at & AT3G21700 & G-protein related & 8541 & $\mathrm{P}$ & 105 & $P$ & 131 & $\mathrm{P}$ & 106 & $\mathrm{P}$ \\
\hline MAPK & 8 & No & 266348_at & AT2G01450 & MPK17 & 9958 & $\mathrm{P}$ & 982 & $\mathrm{P}$ & 1039 & $\mathrm{P}$ & 1051 & $\mathrm{P}$ \\
\hline MAPK & 6 & $\underline{\text { No }}$ & 249239_at & AT5G41990 & ZIK6 & 3363 & $P$ & 325 & $\mathrm{P}$ & 604 & $\mathrm{P}$ & 620 & $\mathrm{P}$ \\
\hline $\begin{array}{l}\text { Phospho- } \\
\text { inositide }\end{array}$ & 74 & Yes & 259425_at & AT1G01460 & $\begin{array}{l}4,5 \text { PIP kinase- } \\
\text { related }\end{array}$ & 6800 & $\mathrm{P}$ & 63 & A & 64 & A & 61 & A \\
\hline $\begin{array}{l}\text { Phospho- } \\
\text { inositide } \\
14-3-3\end{array}$ & 19 & Yes & 251711_at & $\underline{\text { AT3G56960 }}$ & $\begin{array}{l}\text { AtPIP5K1 } \\
\text { 14-3-3 protein }\end{array}$ & 1446 & $\mathrm{P}$ & 52 & A & 45 & A & 64 & $\mathrm{P}$ \\
\hline $\begin{array}{l}\text { protein } \\
\text { Hormone }\end{array}$ & 29 & Yes & 261015_at & AT1G26480 & GF14 iota (grf12) & ) 1177 & $\mathrm{P}$ & 25 & A & 28 & A & 23 & A \\
\hline $\begin{array}{l}\text { metabolism } \\
\text { (auxin) }\end{array}$ & 229 & Yes & 263144_at & AT1G54070 & $\begin{array}{l}\text { Similar to auxin- } \\
\text { repressed protein }\end{array}$ & 13841 & $\mathrm{P}$ & 40 & A & 38 & A & 59 & A \\
\hline $\begin{array}{l}\text { Hormone } \\
\text { metabolism } \\
\text { (auxin) }\end{array}$ & 192 & Yes & 257121_at & АT3G20220 & $\begin{array}{l}\text { Putative auxin- } \\
\text { induced protein }\end{array}$ & 13022 & $\mathrm{P}$ & 39 & A & 38 & A & 63 & A \\
\hline $\begin{array}{l}\text { Hormone } \\
\text { metabolism } \\
\text { (ethylene) }\end{array}$ & 9 & No & 254434_at & AT4G20880 & ERT2 & 3440 & $P$ & 319 & $\mathrm{P}$ & 272 & $P$ & 392 & $\mathrm{P}$ \\
\hline $\begin{array}{l}\text { Hormone } \\
\text { metabolism } \\
\text { (ethylene) }\end{array}$ & 3 & No & 257981_at & АТЗG20770 & EIN3 & 3236 & $\mathrm{P}$ & 869 & $\mathrm{P}$ & 743 & $\mathrm{P}$ & 703 & $P$ \\
\hline $\begin{array}{l}\text { Hormone } \\
\text { metabolism } \\
\text { (cytokinin) }\end{array}$ & 31 & No & 245477_at & AT4G16110 & $\begin{array}{l}\text { Response } \\
\text { regulator ARR2 }\end{array}$ & 353 & $\mathrm{P}$ & 129 & $\mathrm{P}$ & 193 & $P$ & 143 & $P$ \\
\hline $\begin{array}{l}\text { Hormone } \\
\text { metabolism } \\
\text { (cytokinin) }\end{array}$ & 2 & No & 257492_at & AT1G49190 & $\begin{array}{l}\text { Response } \\
\text { regulator ARR19 } \\
\text { Putative }\end{array}$ & 1453 & $\mathrm{P}$ & 68 & A & 45 & A & 62 & $\mathrm{P}$ \\
\hline $\begin{array}{l}\text { Hormone } \\
\text { metabolism } \\
\text { (ABA) }\end{array}$ & 11 & Yes & 254668 at & AT4G18350 & $\begin{array}{l}\text { neoxanthin } \\
\text { cleavage enzyme } \\
\text { (NC1)(NCED1) }\end{array}$ & 251 & $P$ & 50 & A & 58 & A & 48 & A \\
\hline $\begin{array}{l}\text { Hormone } \\
\text { metabolism } \\
\text { (ABA) }\end{array}$ & 4 & Yes & 248227_at & AT5G53820 & $\begin{array}{l}\text { ABA-inducible } \\
\text { protein-like }\end{array}$ & 931 & $\mathrm{P}$ & 25 & A & 25 & A & 18 & A \\
\hline
\end{tabular}

Examples of genes that are most upregulated in pollen relative to vegetative tissues (i.e. leaves, seedlings and siliques) are listed for most of the functional classes shown in Figure 1. The second column contains the lower confidence bound of the fold change in gene expression (an average of the comparisons of pollen to the three vegetative tissues). The fourth and the fifth columns give the Affymetrix probe set and the TAIR locus (AGI ID) assigned to this probe set. In the following columns the expression value [How is this expression value derived?] of the gene (weighted average of duplicates) and its detection call (present $[\mathrm{P}]$ or absent $[\mathrm{A}]$ ) are given for the respective cell type or tissue [Could you please clarify how the presence or absence of an detection call is determined. Why aren't all of the genes present since they all have an expression value in all tissues?]. The genes AT5G28680 and AT1G54070 belong to the 25 most-upregulated genes in pollen. ARR2, AUXIN RESPONSE REGULATOR2; AtPIP5K1, XXX; AtRABA1i, XXX; CPK24, XXX; CRPK1L, xxx; EIN3, ETHYLENE INSENSITIVE3; ERT3, XXX; GF14 iota, XXXX; grf12, XXXX; LRR III, LEUCINE-RICH RECEPTOR III; NC1, NEOXANTHIN CLEAVAGE1; NCED1, XXX; RLCKVII, XXX; SGP1, XXX; ZIK6, XXX. [Please define all abbreviations that are not mentioned elsewhere in the review.]

\section{7}

218 vegetative tissues). When looking at genes whose 219 transcripts are enriched in pollen, however, this number 220 goes up to $26 \%$, making signalling genes the most 221 prominent class by far (JD Becker et al., unpublished;
223 Table 1, Figure 2). These numbers have not yet been 224 backed up by data from root hairs. Comparison of the 225 pollen and root-hair transcriptomes could, however, 226 allow a better comparison of the signalling pathways in 
these tip-growing cells and help to identify the fundamental signalling processes that underlie tip growth in plant cells.

230 Nevertheless, the obvious complexity deployed in the 231 signalling pathways of tip-growing cells (Figure 2) makes it a difficult to comprehend how these pathways are integrated and coordinated to produce a specific phenotype. Although probably a reductionist thought, it could well be that a great deal of this integration, especially in space and time, is based on smaller diffusible entities that affect multiple levels of the canonical signalling pathways by direct biochemical or biophysical actions. Hence, we now explore emerging evidence of the involvement of two such groups: free ions and radicals.

\section{Enter the ions!}

Certain ions have long been known to encode information, acting as second messengers in important signalling pathways [Please cite [24] in correct order.] $[25,26]$. Calcium ions have received particular attention $[27,28]$, mostly because of the so-called ' $\mathrm{Ca}^{2+}$ signature' but probably also because of the existence of $\mathrm{Ca}^{2+}$ switches [29]. Recent genetic evidence showed that $\mathrm{Ca}^{2+}$-ATPases are fundamental for pollen-tube growth $\left[30^{\circ}\right]$. Potassium ions also seem to play a role in this process [31] and chloride appears to be linked to the phosphatidylinositol signalling pathway, which is also involved in tip growth [32]. Moreover, life as we know it occurs in aqueous media. Since water spontaneously ionises, cells live in a 'proton world' and any change in $\mathrm{pH}$ will have an impact on a variety of molecules in different ways. Therefore, the most sophisticated information on $\mathrm{Ca}^{2+}$ and other ions is of limited value as long as the $\mathrm{pH}$ condition of the cell is not also determined [33].

A great deal of controversy still exists regarding a possible role for $\mathrm{pH}$ as a signal messenger. This controversy is mainly due to the extremely high conductivity of protons and the presumed consequent dissipation of any transiently formed gradient. It is also true, however, that this same property makes protons ideal candidates for encoding/decoding signals that operate with very short time frames, which are difficult to resolve with the techniques used at present. Conceivably, self-sustained proton waves could underlie fast calcium waves, which are known to propagate in a variety of cell types [34]. Pollen tubes have been successfully used as a model system for studies of ion dynamics in tip growth [26]. Among other ion fluxes, pollen tubes have been shown to contain a tip-focused $\mathrm{pH}$ gradient, with an acidic tip being associated with growth and a constitutive subapical alkaline region [35].

Both pollen tubes and root hairs have been shown to display 'short-circuits' of extracellular proton fluxes around their tips, a result hypothesised to reflect a polarised distribution of proton pumps ([36]; Figure 3). This model has recently been confirmed using
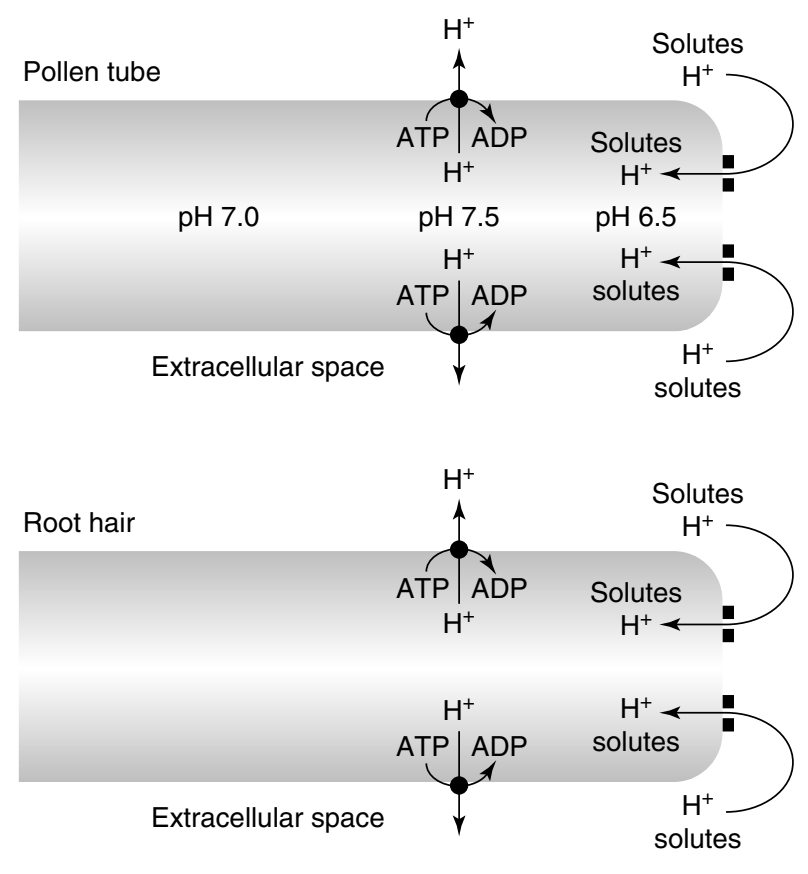

Figure 3

A model for proton gradients in pollen tubes and root hairs. The existence of 'short-circuits' of extracellular proton fluxes around the tips of pollen tubes and root hairs, a result hypothesised to reflect a polarised distribution of proton pumps, could conceptually constitute a powerful sensor of the external milieu if intracellular mechanisms exist to decode small flux variations and to transform them into signalling information (adapted from [36]).
294

295 molecular techniques for pollen tubes (AC Certal et al., unpublished), reinforcing the idea that proton dynamics may be an endogenous mechanism for determining and maintaining the polarity axis in these fast growing cells. The existence of this closed loop of proton fluxes could conceptually constitute a powerful sensor of the external milieu if intracellular mechanisms exist to decode small flux variations and to transform them into signalling information. Acidification of the cell wall, a mechanism that may be conveyed through ethylene, also seems to initiate root hairs [37]. Interestingly, new evidence is starting to reveal that $\mathrm{pH}$ may also play an important role in the cascade of events that lead to oxidative burst in guard cells. In these cells, an alkalinization seems to underlie both the abscisic acidor methyl-jasmonate-induced formation of reactive oxygen species (ROS) and stomatal closure [38]. Alkalinization is also involved upstream of the cytoskeleton in the signalling cascade that leads to the gravitropic response in roots [39]. In short, there is accumulating evidence for the existence of a proton signature. This signature would act as a signalling mechanism that underlies the development of tipgrowing and possibly other kinds of plant cells, and there is no shortage of distinct physico-chemical properties that are associated with protons to test these assumptions [40]. 


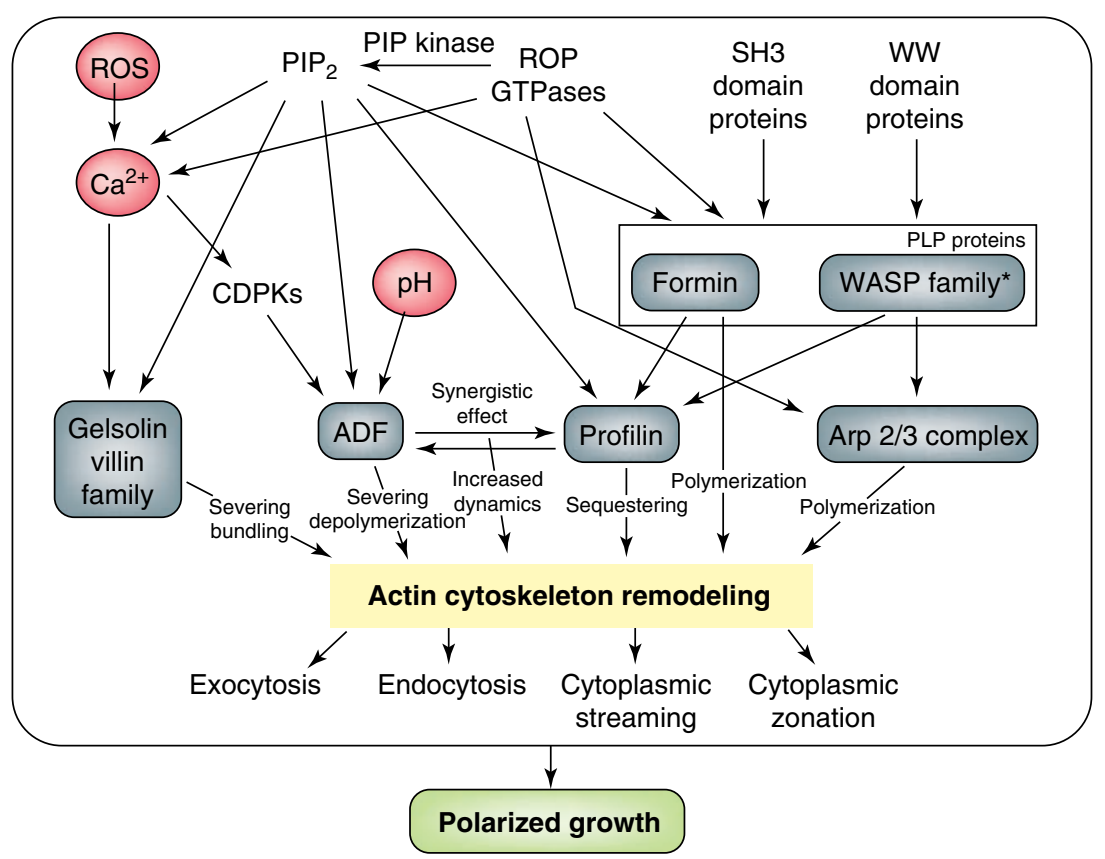

Figure 4

Current Opinion in Plant Biology

Signalling pathways to the actin cytoskeleton. The major signalling pathways known to have a connection to the actin cytoskeleton involve the action of ROS, ROP GTPases and PIP2 [Please define PIP2.], but the majority of the effectors of these pathways and the interconnections between them remain unknown. The actin-binding proteins represented in this scheme are the best characterized in plants, but others (e.g. capping protein $[C P]$ and AIP1) are starting to be characterized. The activity of these proteins must be tightly regulated for polarised growth to occur in an effective way. In plants, profilin and ADF are a fulcral point in the regulation of actin dynamics. They act synergistically to increase actin filament dynamics. ADF promotes the generation of new barbed-ends, and profilin delivers the monomers to the uncapped barbed-ends for polymerisation. It is important to highlight the fact that, in pollen tubes, only formins have been described as actin-filament nucleators; whereas, in root hairs, the Arp2/3 complex seems to be responsible for the same function. The only members of the poly-L-profilin-binding (PLP) proteins to be conserved in plants are formins. Hence, a partner other than the WASP family of proteins must regulate the Arp2/3 complex. CDPKs, calciumdependent protein kinases.

\section{And life met oxygen}

2.5 billion years ago life met oxygen. A new aerobic environment directed the evolution of biochemical pathways towards the use of ROS. One of the ROS generation systems described in plants is dependent on NADPH-oxidase activity. Its activation requires the participation of the small cytosolic GTPase Rac2 (see Yang, this issue). The cytoplasmic amino-terminal region of this GTPase contains two putative EF-hand motifs, suggesting a that it is regulated by $\mathrm{Ca}^{2+}$ ions $[41,42]$. Ten putative genes encode GTPases in Arabidopsis and some of these genes function in abscisic acid (ABA) signalling [43․ . A new exciting area in ROS signalling was opened up by the discovery of the roothair defective2 (rhd2) Arabidopsis mutant, which has a defect in one catalytic subunit of the NADPH-oxidase. In root hairs, as in pollen tubes, the maintenance of $\mathrm{Ca}^{2+}$ transport across the membrane and the presence of a tip-focused $\left[\mathrm{Ca}^{2+}\right]$ gradient are fundamental [For what? Please clarify.]. The $r h d 2$-phenotype is characterised by short root hairs and stunted roots, and no $\left[\mathrm{Ca}^{2+}\right]$ gradient could be observed in the root hairs of these mutants [44]. Because rhd2 mutants show defects in the steady tip-focused $\left[\mathrm{Ca}^{2+}\right]$ gradient, it was hypothesised that ROS are required to stimulate $\mathrm{Ca}^{2+}$ influx during roothair elongation. This was shown through an elegant experiment in which root-hair spheroplasts were
363 released by laser microsurgery from the apices of young 364 root hairs and rdh2 bulges. Using patch-clamp and 365 indirect ROS imaging, Foreman et al. [45 ${ }^{\circ}$ ] were able to 366 observe the activation of hyperpolarization-activated $367 \mathrm{Ca}^{2+}$ channels by ROS. Thus, ROS appear to act 368 upstream of $\left[\mathrm{Ca}^{2+}\right]$ in the signalling cascade, triggering a $369\left[\mathrm{Ca}^{2+}\right]$ rise and a putative subsequent modulation of 370 actin dynamics that underlies polarised growth.

371 ROS have also been implicated in the curling response 372 that occurs during the Rhiwobium-legume symbiosis 373 [46]. In Medicago truncatula, the nodulation (Nod)-factor 374 response interfered with the elicitation of $\mathrm{H}_{2} \mathrm{O}_{2}$ efflux; 375 instead of the oxidative burst found in plant defence 376 responses, ROS production decreases in the presence of 377 a symbiotic signal [46,47]. Finally, ROS have been 378 described as having a mechanistic role in Fucus rhizoid 379 development [48]. Hyper-osmotic treatment of Fucus 380 rhizoids induces a $\left[\mathrm{Ca}^{2+}\right]$ wave and peripheral ROS 381 production. Inhibition of the NADPH-oxidase blocked 382 this $\left[\mathrm{Ca}^{2+}\right]$ wave. Further it was shown that increased 383 cytosolic $\left[\mathrm{Ca}^{2+}\right]$ was sufficient to induce ROS production 384 in mitochondria. This growing body of evidence to 385 describe the signalling links that occur after ROS 386 activation of $\mathrm{Ca}^{2+}$ channels have recently been 387 promoted to a general theory of polar growth, hormone 388 transduction, stress signalling and hypothetically 389 mechanotransduction [49]. Direct gene activation is, for 
390 the moment, excluded from these generalisations 391 because no transcription factor or promoter element 392 that is redox sensitive is yet known in plants [41]. 393 Nevertheless, transcriptional activation in eukaryotic 394 cells does seem to be influenced by redox status. 395 Indeed, redox status is known to regulate the 396 expression of several plant genes, and there are several 397 candidates for promoter elements that are 398 DNA-binding factors that may act as redox-response 399 elements [41,50]. Indirect effects of ROS on the activity 400 of a transcription factor activity have also been reported 401 through the activation of mitogen-activated protein 402 kinase (MAPK) [51].

\section{Dynamic skeletons: where all things come 404 together?}

405 ROP GTPases (Yang, this issue), ionic gradients [52], 406 lipids [17,53,54], and cyclic nucleotide levels [55], [10“] 407 all participate in signalling pathways that are known to 408 affect the cytoskeleton. Actin-binding proteins are 409 believed to integrate this information and to transduce 410 it to alterations in the cytoskeleton [56]. For example, 411 actin-depolymerising factor (ADF) and profilin act 412 synergistically to affect actin dynamics: ADF generates 413 more filament ends for polymerisation through its 414 severing activity and by enhancing the dissociation of $415 \mathrm{G}$-actin from slow-growing ends; profilins bind to $416 \mathrm{G}$-actin and thus are incorporated in the free barbed 417 end. Both ADF and profilin respond to ionic conditions. 418 The actin-severing activity of ADF is $\mathrm{pH}$ dependent, 419 whereas profilin's activity is $\mathrm{Ca}^{2+}$ dependent. 420 Mechanisms for the regulation of ADF also include 421 inhibition by both phosphorylation by a calmodulin-like 422 domain protein kinase and membrane lipid binding. $423 \mathrm{ADF}$ is involved in the regulation of pollen-tube growth 424 and uses the same signalling pathway as Rac/Rop 425 GTPase [57].

426 Poly-L-profilin-binding (PLP) proteins (i.e. Wiskott427 Aldrich syndrome protein [WASP], VASP [Please 428 define this abbreviation.] and formins) play a very 429 important role in the signalling pathway cascades that 430 affect the cytoskeleton in animal and yeast cells. These 431 proteins are known to respond to Rho GTPases and to 432 SH3- and WW-domain proteins, and to induce actin 433 filament remodelling and nucleation. Formin 434 overexpression in pollen tubes was recently shown to 435 stimulate the production of supernumerary actin cables 436 from the plasma membrane [58 ]. Furthermore, 437 overexpression of the formin AFH1 from Arabidopsis 438 resulted in the formation of pollen tubes that had 439 increased diameter, tip expansion and growth arrest, 440 suggesting that formins are involved in the regulation of 441 polarised growth. By contrast, low levels of AFH1 result 442 in the production of pollen tubes with normal 443 morphology and stimulate growth. Arp2/3 is involved in 444 the polymerisation of branched networks of actin 445 filaments in animal cells and yeast. In root hairs, Arp2/3 446 has a crucial role because these cells become sinuous in 447 Arp2 (wurm) and Arp3 (distorted1) Arabidopsis mutants
[59]. The same result was obtained by the mutation of the small subunit of the Arp2/3 complex (producing crooked mutants) [60]. Arp2/3 may also be involved in endocytosis as recently shown in yeast [61]. The bestcharacterized activators of the Arp2/3 complex are members of the WASP and contractin protein families. Because WASP and contractin proteins have still not been identified in plants, it remains to be established if this is also the case or if new effectors are to be found in plants.

One of the most-studied signalling pathways in root hairs is elicited by Nod factors, which are lipochitooligosaccharides produced by the bacterium Rhizobium spp. Upon rhizobial infection, the responses of root hairs include swelling, membrane depolarisation, oscillations in calcium concentrations [62], cell-wall loosening, alterations in root-hair growth and the expression of host nodulation genes. The cytoskeleton is one of the targets of this system $[63,64]$. Recently, ACTIN-INTERACTING PROTEIN1 (AIP1) was suggested to be essential for the organisation of the actin cytoskeleton in plant cells [65]. As well as being a co-operator with the ADF protein, AIP1 has a capping activity, which enhances its activity. Cell expansion is compromised in plants in which AIP1 is silenced by RNA interference (RNAi) These plants showed thick actin bundles in all of the cell-types analysed, including root hairs (pollen was not studied). Hence, it seems that all of the proteins that coordinate the dynamics of the actin cytoskeleton must be tightly regulated in order for polarised and directional growth to take place. Conceivably, these proteins could be the major computational integrator of all of the diverse signalling machineries that contribute to tip growth (Figure 4).

\section{Conclusions}

New molecules continue to be described as important players in tip-growing cells. These include protein kinases, lipids, and molecules that have neurotransmitter activities in animals. Transcriptomics has shown that genes that are involved in signal transduction form the largest single class of genes that are more-represented in pollen tubes than in non-tipgrowing cells, reflecting their capacity to decode all of the different contributing pathways. Many of these pathways may use common intracellular second messengers, and ions and ROS are emerging as two major common denominators in many of the processes involved in tip growth. Ultimately, the second messengers should influence the actin cytoskeleton through known interactions with actin-binding proteins. In turn, changes in the dynamics properties of the cytoskeleton define the basic polarity events needed to shape and modify tip-growing cells.

\section{Acknowledgements}

We thank Sheila McCormick, Alice Cheung and Liam Dolan for comments and critical reading of the manuscript. Research in JAF's laboratory is supported by FCT/POCTI grants (POCTI/BIA/34772/1999, POCTI/BCI/41725/2001 and POCTI/BCI/46453/2002) and fellowships for JDB (SFRH/BPD/3619/2000), ACC (POCTI/BD19874/99 and 
508 POCTI/BPD14697/2003), SSC (SFRH/BD/6453/2001) and AMP 509 (SFRH/BD/6278/2001).

\section{References and recommended reading}

511 Papers of particular interest, published within the annual period of review, have been highlighted as:

- of special interest

.• of outstanding interest

515 1. Yang Z: Signaling tip growth in plants. Curr Opin Plant

$$
\text { Biol 1998, 1:525-530. }
$$

2. Ryan $\mathrm{E}$, Steer M, Dolan L: Cell biology and genetics of root hair formation in Arabidopsis thaliana. Protoplasma 2001, 215:140-149.

3. Taylor LP, Hepler PK: Pollen germination and tube growth. Annu Rev Plant Physiol Plant Mol Biol 1997, 48:461-491.

4. Grierson C, Ketelaar T: Development of root hairs. In The Plant Cytoskeleton in Cell Differentiation and Development. Edited by Hussey PJ. [Place of publication missing.]: Blackwell/CRC Press; 2004:207-238.

5. McCormick S: Control of male gametophyte development. Plant Cell 2004, 16:S142-S153.

6. Tang W, Ezcurra I, Muschietti J, McCormick S: A cysteinerich extracellular protein, LAT52, interacts with the extracellular domain of the pollen receptor kinase LePRK2. Plant Cell 2002, 14:2277-2287.

••7. Wengier D, Valsecchi I, Cabanas ML, Tang WH, McCormick S, Muschietti J: The receptor kinases LePRK1 and LePRK2 associate in pollen and when expressed in yeast, but dissociate in the presence of style extract. Proc Natl Acad Sci USA 2003, 100:6860-6865.

The interaction between LePRK2 and Lat52 identifies the possibility of an autocrine signalling system. The LePRK signalling pathway is atypical, but not unique, when compared with other signalling systems in plants and animals. The binding of a ligand to the extracellular domain of LePRK triggers receptor dephosphorylation and LePRK complex dissociation. Subsequently, receptor auto-phosphorylation and complex assembly usually takes place. The authors also present some evidence to support a model for pollen-pistil interactions, in which different pistil ligands subsequently bind to pollen receptors along the style.

8. Tang W, Kelley D, Ezcurra I, Cotter R, McCormick S: LeSTIG1, an extracellular binding partner for the pollen receptor kinases LePRK1 and LePRK2, promotes pollen tube growth in vitro. Plant J 2004, in press.

•.9. Palanivelu R, Brass L, Edlund AF, Preuss D: Pollen tube growth and guidance is regulated by POP2, an Arabidopsis gene that controls GABA levels. Cell 2003, 114:47-59.

The authors use genetic and cellular approaches to demonstrate that the neurotransmitter GABA may have a role in pollen-stigma communication. pop2, which has abnormalities in pollen directional guidance, was shown to be a GABA-degrading transaminase. Its function may involve sensing external GABA from the female tissues.

• 10. Prado AM, Porterfield DM, Feijo JA: Nitric oxide is involved in growth regulation and re-orientation of pollen tubes. Development 2004, 131:2707-2714.

In this work, the authors show that lily pollen tubes have a negative tropic response to external gradients of $\mathrm{NO}$ in vitro. The re-orientation response is downregulated by cGMP, and a new candidate molecule for in-vivo guidance of pollen tubes is hypothesised.

11. Ignarro JL: Nitric oxide biology and patholobiology. Edited by Ignarro JL. [City of publication missing.]: Academic Press; 2000:3-380.

12. Lamattina L, Garcia-Mata $C$, Graziano M, Pagnussat G: Nitric oxide: the versatility of an extensive signal molecule. Annu Rev Plant Biol 2003, 54:109-136.
13. del Rio LA, Corpas FJ, Barroso JB: Nitric oxide and nitric oxide synthase activity in plants. Phytochemistry 2004, 65:783-792.

14. Guo FQ, Okamoto M, Crawford NM: Identification of a plant nitric oxide synthase gene involved in hormonal signaling. Science 2003, 302:100-103.

15. Chandok MR, Ytterberg AJ, van Wijk KJ, Klessig DF: The pathogen-inducible nitric oxide synthase (iNOS) in plants is a variant of the $P$ protein of the glycine decarboxylase complex. Cell 2003, 113:469-482.

16. Lamattina L, Garcia-Mata C, Graziano M, Pagnussat G: Nitric oxide: the versatility of an extensive signal molecule. Annu Rev Plant Biol 2003, 54:109-136.

17. Wang XM: Lipid signaling. Curr Opin Plant Bio/ 2004, 7:329-336

-18. Ohashi Y, Oka A, Rodrigues-Pousada R, Possenti M, Ruberti I, Morelli G, Aoyama T: Modulation of phospholipid signaling by GLABRA2 in root-hair pattern formation. Science 2003, 300:1427-1430.

See annotation for [20].

-19. Potocky M, Elias M, Profotova B, Novotna Z, Valentova O, Zarsky V: Phosphatidic acid produced by phospholipase $D$ is required for tobacco pollen tube growth. Planta 2003, 217:122-130.

See annotation for $\left[20^{\circ}\right]$.

-20. Zonia L, Munnik T: Osmotically induced cell swelling versus cell shrinking elicits specific changes in phospholipid signals in tobacco pollen tubes. Plant Physio/ 2004, 134:813-823.

The authors of $\left[18^{\circ}-20^{\circ}\right]$ establish very solid foundations for a phosphatidic acid and phospholipase-based signaling system in tip-growing cells. Furthermore, Zonia and Munnik demonstrate a link from this signalling system to the phosphatidylinositide phosphate pathway.

-21. Becker JD, Boavida LC, Carneiro J, Haury M, Feijo JA:

Transcriptional profiling of Arabidopsis tissues reveals the unique characteristics of the pollen transcriptome. Plant Physiol 2003, 133:713-725.

The authors compare the transcriptional profile of cell-sorted pollen grains with those of four vegetative tissues (i.e. seedlings, leaves, roots, and siliques) using Affymetrix 8K Arabidopsis GeneChips. They identify $10 \%$ of the genes as being selectively expressed in pollen and provide a functional classification for them.

-22. Honys D, Twell D: Comparative analysis of the

Arabidopsis pollen transcriptome. Plant Physiol 2003, 132:640-652.

The transcriptome of non-sorted pollen grains is compared with those of four developmental stages of the sporophyte (using Affymetrix 8K Arabidopsis GeneChips). 40\% of the genes that were expressed in pollen were identified as being expressed specifically in that tissue.

-23. Lee JY, Lee DH: Use of serial analysis of gene expression technology to reveal changes in gene expression in Arabidopsis pollen undergoing cold stress. Plant Physiol 2003, 132:517-529.

The authors compare the transcriptome of pollen under normal conditions with that of pollen under chilling conditions and that of leaves. Using SAGE, they identify 4211 tags that are unique to pollen and characterise the functional classes they represent.

24. Thimm O, Blasing O, Gibon Y, Nagel A, Meyer S, Kruger P, Selbig J, Muller LA, Rhee SY, Stitt M: MAPMAN: a userdriven tool to display genomics data sets onto diagrams of metabolic pathways and other biological processes. Plant J 2004, 37:914-939.

25. Feijó JA, Sainhas J, Holdaway-Clarke T, Cordeiro MS, Kunkel JG, Hepler PK: Cellular oscillations and the regulation of growth: the pollen tube paradigm. Bioessays 2001, 23:8694. 
26. Holdaway-Clarke TL, Hepler PK: Control of pollen tube growth: role of ion gradients and fluxes. New Phyto/ 2003, 159:539-563.

27. Hetherington $A M$, Brownlee C: The generation of $\mathrm{Ca}^{2+}$ signals in plants. Annu Rev Plant Physiol Plant Mol Biol 2004, 55:401-427.

28. Harper JF, Breton G, Harmon A: Decoding $\mathrm{Ca}^{2+}$ signals through plant protein kinases. Annu Rev Plant Physiol Plant Mol Biol 2004, 55:263-288.

29. Scrase-Field $S$, Knight MR: Calcium: just a chemical switch? Curr Opin Plant Biol 2003, 6:500-506.

-30. Schiott M, Romanowsky SM, Baekgaard L, Jakobsen MK, Palmgren MG, Harper JF: A plant plasma membrane $\mathrm{Ca}^{2+}$ pump is required for normal pollen tube growth and fertilization. Proc Natl Acad Sci USA 2004, 101:95029507.

The authors establish that a novel $\mathrm{Ca}^{2+}$-ATPase is fundamental for pollen-tube growth, implying that the active pumping of $\mathrm{Ca}^{2+}$ is necessary for tip growth. A green fluorescent protein (GFP)-fusion with this ATPase is localisation in the plasma membrane throughout the periphery of the cell, so the pump might not be involved in polarity directly. Nevertheless, but the data show that overall $\left[\mathrm{Ca}^{2+}\right]$ homeostasis may be a critical aspect of tip growth.

31. Mouline K, Very AA, Gaymard F, Boucherez J, Pilot G, Devic $M$, Bouchez D, Thibaud JB, Sentenac H: Pollen tube development and competitive ability are impaired by disruption of a Shaker $\mathrm{K}(+)$ channel in Arabidopsis. Genes Dev 2002, 16:339-350.

32. Zonia L, Cordeiro S, Tupy J, Feijo JA: Oscillatory chloride efflux at the pollen tube apex has a role in growth and cell volume regulation and is targeted by inositol 3,4,5,6-tetrakisphosphate. Plant Cell 2002, 14:2233-2249.

33. Felle $\mathrm{HH}$ : $\mathrm{pH}$ : signal and messenger in plant cells. Plant Biology 2001, 3:577-591.

34. Jaffe LF: A proton-led model of fast calcium waves. Cell Calcium 2004, 36:83-87.

35. Feijo JA, Sainhas J, Hackett GR, Kunkel JG, Hepler PK: Growing pollen tubes possess a constitutive alkaline band in the clear zone and a growth-dependent acidic tip. J Cell Biol 1999, 144:483-496.

36. Palmgren MG: PLANT PLASMA MEMBRANE $\mathrm{H}^{+}$-ATPases: powerhouses for nutrient uptake. Annu Rev Plant Physiol Plant Mol Biol 2001, 52:817-845.

37. Takahashi $H$, Kawahara $A$, Inoue $Y$ : Ethylene promotes the induction by auxin of the cortical microtubule randomization required for low-pH-induced root hair initiation in lettuce (Lactuca sativa L.) seedlings. Plant Cell Physiol 2003, 44:932-940.

38. Suhita D, Raghavendra AS, Kwak JM, Vavasseur A: Cytoplasmic alkalization precedes reactive oxygen species production during methyl jasmonate- and abscisic acid-induced stomatal closure. Plant Physiol 2004, 134:1536-1545.

39. Hou G, Kramer VL, Wang YS, Chen R, Perbal G, Gilroy S, Blancaflor EB: The promotion of gravitropism in Arabidopsis roots upon actin disruption is coupled with the extended alkalinization of the columella cytoplasm and a persistent lateral auxin gradient. Plant $J 2004$, 39:113-125.

40. Decoursey TE: Voltage-gated proton channels and other proton transfer pathways. Physiol Rev 2003, 83:475-579.

41. Apel K, Hirt H: Reactive oxygen species: metabolism, oxidative stress, and signal transduction. Annu Rev Plant Physiol Plant Mol Biol 2004, 55:373-399.

42. Keller T, Damude HG, Werner D, Doerner P, Dixon RA, Lamb C: A plant homolog of the neutrophil NADPH oxidase gp91phox subunit gene encodes a plasma membrane protein with $\mathrm{Ca}^{2+}$ binding motifs. Plant Cell 1998, 10:255 266.

-43. Kwak JM, Mori IC, Pei ZM, Leonhardt N, Torres MA, Dangl JL, Bloom RE, Bodde S, Jones JDG, Schroeder JI: NADPH oxidase $A$ trbohD and AtrbohF genes function in ROS-dependent ABA signaling in Arabidopsis. EMBO J 2003, 22:2623-2633.

The exploration of NADPH oxidase Arabidopsis mutants provides a genetic demonstration of the links between $A B A$ and ROS signaling.

44. Wymer CL, Bibikova TN, Gilroy S: Cytoplasmic free calcium distributions during the development of root hairs of Arabidopsis thaliana. Plant J 1997, 12:427-439.

••45. Foreman J, Demidchik V, Bothwell JH, Mylona P, Miedema H, Torres MA, Linstead P, Costa S, Brownlee C, Jones JD et al:: Reactive oxygen species produced by NADPH oxidase regulate plant cell growth. Nature 2003, 422:442-446

In this work, the authors show that the Arabidopsis rhd2 is defective in one catalytic subunit of a NADPH-oxidase that is responsible for ROS generation. They prove that ROS stimulate the activity of a plasma membrane hyperpolarization-activated $\mathrm{Ca}^{2+}$ channels. This shows the importance of ROS and NADPH oxidases in maintaining the tip-high $\left[\mathrm{Ca}^{2+}\right]$ gradient during root-hair development.

46. Herouart D, Baudouin E, Frendo P, Harrison J, Santos R, Jamet A, Van de Sype G, Touati D, Puppo A: Reactive oxygen species, nitric oxide and glutathione: a key role in the establishment of the legume-Rhizobium symbiosis? Plant Physiol Biochem 2002, 40:619-624.

47. Shaw SL, Long SR: Nod factor inhibition of reactive oxygen efflux in a host legume. Plant Physiol 2003, 132:2196-2204.

48. Coelho SM, Taylor AR, Ryan KP, Sousa-Pinto I, Brown MT, Brownlee C: Spatiotemporal patterning of reactive oxygen production and $\mathrm{Ca}(2+)$ wave propagation in Fucus rhizoid cells. Plant Cell 2002, 14:2369-2381.

49. Mori IC, Schroeder JI: Reactive oxygen species activation of plant $\mathrm{Ca}^{2+}$ channels. A signaling mechanism in polar growth, hormone transduction, stress signaling, and hypothetically mechanotransduction. Plant Physiol 2004, 135:702-708.

50. Vranova $E$, Inze D, Van Breusegem F: Signal transduction during oxidative stress. J Exp Bot 2002, 53:1227-1236.

51. Laloi $C$, Apel K, Danon A: Reactive oxygen signalling: the latest news. Curr Opin Plant Biol 2004, 7:323-328.

52. Yang TB, Poovaiah BW: Calcium/calmodulin-mediated signal network in plants. Trends Plant Sci 2003, 8:505512.

53. Meijer HJ, Munnik T: Phospholipid-based signaling in plants. Annu Rev Plant Biol 2003, 54:265-306.

54. Yin HL, Janmey PA: Phosphoinositide regulation of the actin cytoskeleton. Annu Rev Physio/ 2003, 65:761-789.

55. Moutinho A, Hussey PJ, Trewavas AJ, Malho R: cAMP acts as a second messenger in pollen tube growth and reorientation. Proc Natl Acad Sci USA 2001, 98:1048110486.

56. Staiger CJ, Hussey PJ: Actin and actin-modulating proteins. In The Plant Cytoskeleton in Cell Differentiation and Development. Edited by Hussey PJ. [City of publication missing.]: Blackwell/ CRC Press; 2004:32-80.

57. Chen $\mathrm{CYH}$, Cheung AY, Wu HM: Actin-depolymerizing factor mediates Rac/Rop GTPase-regulated pollen tube growth. Plant Cell 2003, 15:237-249.

-58. Cheung AY, Wu HM: Overexpression of an Arabidopsis formin stimulates supernumerary actin cable formation from pollen tube cell membrane. Plant Cell 2004, 16:257269. 
781 The authors demonstrate that formins are involved in the process of 782 actin nucleation in pollen, as well as in the regulation of polarised 783 growth. They provide some evidence on the possible regulation of 784 membrane structure by actin filaments. Formins are proposed as 785 new components of the signalling crosstalk between pollen and the 786 female tissues.

59. Mathur J, Mathur N, Kernebeck B, Hulskamp M: Mutations in actin-related proteins 2 and 3 affect cell shape development in Arabidopsis. Plant Cell 2003, 15:16321645.

60. Mathur J, Mathur N, Kirik V, Kernebeck B, Srinivas BP, Hulskamp M: Arabidopsis CROOKED encodes for the smallest subunit of the ARP2/3 complex and controls cell shape by region specific fine F-actin formation. Development 2003, 130:3137-3146.

61. Kaksonen M, Sun Y, Drubin DG: A pathway for association of receptors, adaptors, and actin during endocytic internalization. Cell 2003, 115:475-487.
62. Shaw SL, Long SR: Nod factor elicits two separable calcium responses in Medicago truncatula root hair cells. Plant Physiol 2003, 131:976-984.

63. Cardenas L, Thomas-Oates JE, Nava N, Lopez-Lara IM, Hepler $\mathrm{PK}$, Quinto $\mathrm{C}$ : The role of nod factor substituents in actin cytoskeleton rearrangements in Phaseolus vulgaris. Mol Plant Microbe Interact 2003, 16:326-334.

806 64. Weerasinghe RR, Collings DA, Johannes E, Allen NS: The 807 distributional changes and role of microtubules in Nod 808 factor-challenged Medicago sativa root hairs. Planta 2003, 809 218:276-287.

810 65. Ketelaar T, Allwood EG, Anthony R, Voigt B, Menzel D, Hussey PJ: The actin-interacting protein AIP1 is essential for actin organization and plant development. Curr Biol 2004, 14:145-149. 
Signalling by tips Feijó et al.

815

816 